\title{
How does gift with purchase influence your satisfaction in online buying?
}

\author{
Ami Luki Andrian ${ }^{1}$, Rokhima Rostiani ${ }^{2 *}$ \\ ${ }^{1}$ Graduates, Department of Management, Faculty of Economics and Business, \\ Universitas Gadjah Mada, Yogyakarta, Indonesia \\ ${ }^{2}$ Department of Management, Faculty of Economics and Business, \\ Universitas Gadjah Mada, Yogyakarta, Indonesia \\ *Corresponding author: rokhima@ugm.ac.id
}

\section{Article Info}

Article history:

Received : 13 June 2020

Accepted : 22 January 2021

Published : 1 July 2021

JEL Classification Code:

M31, M37, L14

Author's email:

amilukia@gmail.com

DOI: 10.20885 /jsb.vol25.iss2.art8

\begin{abstract}
Purpose: This study tries to examine the effectiveness of gift with purchase when utilized in a social media platform, measured through several variables: perceived usefulness, perceived quality, perceived ingenuity, and perceived cost. We believe that gift with purchase evoke a sense of surprise that leads individual to feel happier thus connects the effectiveness with happiness that subsequently influence individual loyalty.
\end{abstract}

Design/methodology/approach: An online survey was conducted on 207 users of social media platforms for at least six months and received free gift with purchase.

Findings: Perceived usefulness and perceived quality significantly influence happiness towards gifts with purchases. Perceived usefulness and perceived quality served as two important predictors for happiness. When consumers perceived they receive more values and benefits and good quality of the gift, their happiness will be significantly higher. Further, this study showed that happiness is a significant predictor for purchase satisfaction. When consumers are happy with their purchase, they report a higher satisfaction level on their buying decision and a particular seller's social media choice.

Research limitations/implications: Results of this study have limited generalization due to sample's characteristics. Further, this study did not differentiate between type of products such as hedonic or utilitarian that might influence how gift with purchase is perceived.

Practical implications: This study provides insight into sellers participating in online shopping through social media to improve promotion strategy. Managers needs to show the information regarding usefulness and quality of free gift with purchase to their customers, thus showcasing the serious effort to keep consumer happy and satisfied.

Originality/value: The inclusion of happiness variable is scant in research that tries to investigate the effect of gift with purchase and satisfaction. Although rare, happiness is closely related to gift with purchase that are free of charge and thus provide fresh insight on how satisfaction is created.

Keywords: Gift with purchase, happiness, satisfaction

\section{Introduction}

The online population and internet penetration in Indonesia have increased for the past five years, categorized based on their usage behavior. APJII (2017) reported that 44.16 percent of internet users accessed the internet via smartphone, 39.28 per cent via notebooks, while only 4.49 percent 
are using personal computers. These facts showed that people are becoming more mobile and flexible. The advancement of internet usage had changed general users' behavior and those who use the internet for productive purposes. More people are engaging in online shopping, either as buyers or sellers. Kemp (2017) showed that online shopping had penetrated more than 24.74 million people in Indonesia, causing its total revenue to increase by triplets during 2016 (Databoks, 2016).

Online shopping presence itself may take many forms, such as marketplace, owned website, or social media. Social media had taken special attention, primarily because of its duality of being online yet still carrying the traditional mechanism (Gaw, 2016). Unlike online retailing, social media transactions are traditional because social media is used as a catalog of products. It tracks consumers' interactions using a message sender application separate from social media, whereas the seller's account uses the payment process. After the customer makes a payment, the seller must check the payment via account mutation. After the payment confirmation process is complete, the seller sends the product through a shipping service. The process is carried out separately and manually so that it requires a longer time compared to transactions on online retail pages where almost all functions have gone through automation.

The number of buying and selling transactions on social media reaches 80 percent of the total transactions with 2.7 million transactions in a day, four times greater than transactions in online retailing (Kemp, 2017). In terms of usage frequency of social media in Indonesia, Kemp (2017) also found that Facebook dominates with 106 million users, followed by Instagram with 108 million users, and YouTube with 86.1 million users. Specifically, internet users in Indonesia spend their time on social media an average of 3 hours, 16 minutes every day. Facebook Indonesia noted that smartphone users in Indonesia check their phones at least 80 times a day. The high usage intensity of social media is then utilized by online sellers to promote their products through the sponsorship feature provided by social media managers on Facebook, Youtube, and Instagram. Therefore, it is not surprising that online transactions through social media had dominated compared to online retailing. From the buyers' perspective, social media's domination in online shopping is caused by several factors such as convenience, access to diverse choice, cheaper price (Krutaine, 2016), more effortless transaction, and intensity of interaction between buyer and seller.

In practice, the competition level among sellers in social media has become very intense; thus, promotion strategy becomes an essential aspect of winning market share. Providing attractive product images, reliable product descriptions, and utilizing celebrities' endorsement has been the most common effort made by sellers to attract new consumers. However, these strategies were not sufficient since consumers can easily witch sellers. Thus, various promotional activities were chosen by sellers in addition to enhance social media presence. In general, the promotion has two types: monetary (such as discounts, vouchers, and coupons) and non-monetary (such as gifts with purchase, free samples, and contest) promotion that is expected to increase buyers' interest to buy and become loyal consumers.

According to Kim \& Koo (2015), gift with purchase is the most effective marketing promotion practices. They argued that gifts can focus on the value of promotion being made, which would affect how consumers evaluate the online store as a whole (Chun \& Hiang, 2016; Lee \& Yi, 2019). Gift with purchase strategy is commonly used in industrial segments such as electronics, cosmetics, non-taxable products, fashion, daily necessities, and snacks (Lee \& Yi, 2017). The existence of gifts with purchase is undoubtedly beneficial for consumers because consumers can have products from an online store without providing meaningful sacrifices.

This research focused on investigating the effectiveness of gifts with purchase-on-purchase satisfaction in the context of the social media platform. Effectiveness of gift with purchase is measured through several variables, such as perceived usefulness, perceived quality, perceived ingenuity, and perceived cost. The researchers believed that gifts with purchase would evoke sense of surprise, thus, induce individual happiness and ultimately influence satisfaction toward the purchase made. The social media platform was chosen due to millennials' frequent traffic. Therefore, understanding millennials' online shopping behavior through social media platforms may provide tremendous insight for managers to modify their promotion strategy through gifts with purchases. 


\section{Literature Review}

Satisfaction and happiness are the two most important variables in this research to be further examined. Satisfaction has been known as being multi-interpretation (Rojas \& Camarero, 2008) in a sense where different individuals would perceive differently toward similar stimuli for satisfaction. In tourism and history, Rojas \& Camarero (2008) defined satisfaction according to two different approaches: cognitive and affective. In the cognitive approach, satisfaction is formed based on the assessment of quality displayed or the comparison between perceived quality and expected quality and the process of confirmation or disconfirmation that shows the level of satisfaction obtained. In an effective approach, satisfaction is illustrated as an art performance that can meet or even exceed consumer expectations.

In online shopping, consumers need a unique online shopping experience to experience purchase satisfaction (Khan et al. 2016). In general, consumers will be satisfied upon receiving purchase incentives (Zhu et al., 2015), which applies equally to gift with purchase. A gift with purchase can increase purchase satisfaction when the product's expectations are met and hinder dissatisfaction towards online purchases experienced by consumers (Zhu et al., 2015). A gift with purchase is defined as gifts received by consumers after they finalize the purchasing process, and the gift was delivered together with the purchased products. Consumers may know the gift before buying the products but, in any case, may also act as a small surprise from sellers for their buyers.

Happiness is a form of emotion associated with objects, either facts or circumstances (Goldman, 2017). The expression "I am happy with the recent stock market movements" is a form of a statement that associates happiness with an object. When we talk about happy people, we tend to refer to people with pleasurable emotions, who care to feel happy or in a good mood (Goldman, 2017). The happy feeling is an emotion, the same emotion, such as feeling angry, scared, or jealous and proud. A person can feel happy in a bad situation when the person has worse expectations. Conversely, if someone has terrible expectations but gets a worse reality, that person will feel unhappy.

According to the emotional assessment theory, occasions considered harmful would cause negative emotions, while experiences that are deemed beneficial will generate positive emotions (Zhu et al., 2015). In the context of a gift with purchase, the gift may trigger happiness as a positive emotion. Happiness is obtained from consumer evaluations of gifts from purchases received through usability, quality, authenticity, and cost.

\section{Perceived Usefulness and Happiness}

Perceived usefulness is achieved when the product provides benefits that meet consumer needs (Moldovan et al., 2011). When consumers benefit from gifts, they will feel happy because the purchases made are not useless (Zhu et al., 2015). Further, they emphasize that gifts with purchases with a high level of usability can make consumers happy, whereas those below consumer expectations may cause disappointment.

Perceived usefulness affects happiness because consumers evoke the affective stage during their experience upon receiving the gift, both positively and negatively. Happiness is one form of emotion (Goldman, 2017), and it came after the affective stage is finished. In the TAM framework, perceived usefulness is assumed as a determinant of individual intention in using technology to improve performance (Davis et al.1989). Individuals use technology if they believe that technology provides them with benefits. Conversely, consumers will not use technology if it does not offer usability or any other benefits. Another study stated that in the context of online purchasing, perceived usefulness is defined as the extent to which consumers believe that online purchases will improve their transactions (Chiu et al. 2009).

H1: Perceived usefulness of gift with purchase positively influences the happiness of the consumers.

\section{Perceived Quality and Happiness}

Perceived quality refers to gifts with purchase to consistently meet consumer needs or expectations (Zhu et al. 2015). Further, they found a relationship between the perceived quality of gifts with purchase and consumer happiness. Gift of high quality can lead to more happiness for consumers 
(Zhu et al. 2015). They will be happy if they receive a good quality product, especially if the gift is obtained free of charge. However, consumers' perception of assessing the quality of gifts with purchases would differ. A gift with purchase is undoubtedly expected to have good quality so that it has a high level of resistance. Rojas and Camarero (2008) found that quality may directly affect satisfaction or indirectly through emotions. Simamora (2002) further stated that perceived quality is the totality of features and characteristics that make a product capable of satisfying needs, both expressed and latent.

In the context of services, Brady and Cronin (2001) stated three dimensions of perceived service quality: output quality, interaction quality, and physical environment quality. The output quality is what consumers get when a production process or consumption process ends and is usually assessed from individual experience. Interaction quality refers to interactions that occur when the service is delivered or consumed; thus, treatment received and responsiveness of employees is essential. Environmental quality refers to the atmosphere or condition in which the service is provided or when the product is sold (Rojas \& Camarero, 2008). Further, Rojas and Camarero (2008) stated that perceived quality relates to the overall assessment that comes from consumers, which gives rise to confirmation or confirmation of consumer expectations. In another study, Zhu et al. (2015) defined perceived quality as the ability of a product to consistently meet consumer needs or expectations in the context of gift with purchase. The high quality of gifts with purchases increases the reliability of these gifts.

H2: Perceived quality of gifts with purchase positively influences happiness toward that gift.

\section{Perceived Cost and Happiness}

The more expensive the gift tends to be more effective in increasing customer satisfaction and providing more value for consumers (Dodds, 1991). Zhu et al. (2015) concluded a relationship between consumers' perceived cost and happiness. The higher the costs incurred by online stores for the gift with purchase, the higher the joy that consumers feel because they do not need to make more sacrifices to get gifts with purchases (Zhu et al., 2015). This allows differences in individual perception of cost. Some consumers value a product through production costs or overall value offered. The price level of a gift received is proportional to the level of individual satisfaction in the context of online retail (Beltramini, 2000). Price can be an indicator of the number of costs or sacrifices needed to obtain a product as well as an indicator to determine the level of product quality (Dodds, 1991). Further, Dodds (1991) said that the higher the price, the higher the perceived quality, and the greater the desire to buy. On the other hand, there is a possibility that more significant sacrifices are needed so that it can reduce the desire to buy.

In a study conducted by Zhu et al. (2015), cost serves as an indicator of the amount of sacrifice issued by marketers or online shop owners for gifts with purchase. In the context of gifts with purchase, the perceived cost is used by consumers to assess the sincerity of marketers or online shop owners in providing a gift with purchases. The hypothesis is formed as followed: H3: Perceived cost of gifts with purchase positively influences happiness toward gifts received.

\section{Perceived Ingenuity and Happiness}

In the context of word-of-mouth, the more original or different a product is from other products, the product tends to be attractive, possesses a certain level of surprise, and may affect how WOM goes viral (Moldovan et al. 2011). Zhu et al. (2015) further examined the effect of perceived ingenuity on consumers' happiness. Ingenuity is defined as a unique ability (Chen, 2012). Gatignon and Xuereb (1997) described the product's ingenuity as a level of product improvement for consumers or companies. According to Debaix and Vanhamme (2003), an original product is new, unique, and different from what already exists in the market. Genuine products are other products that are already on the market because they have the latest technology. From the consumer perspective, ingenuity is defined as the product's uniqueness relative to previous conditions (Moldovan et al. 2011).

Perceived ingenuity in the context of gifts with purchase lies in the 'unusual' and 'interesting' product (Zhu et al. 2015). Vanhamme (2008) found that the authenticity of the gift can surprise 
consumers. In this regard, consumers will use perceived authenticity to assess gift with purchases (Zhu et al. 2015) because authenticity attributes have unique properties for each product (Vanhamme, 2008). The higher the level of perceived ingenuity of gift with purchase, the greater the happiness consumers will have towards gift received (Zhu et al. 2015).

H4: Perceived ingenuity of gift with purchase positively influences happiness toward gifts received

\section{Happiness and Purchase Satisfaction}

Consumer shopping experience or satisfaction is usually expressed through various emotional changes (Thuraru et al. 2006). Emotional changes are formed as a manifestation of satisfaction felt by consumers for a product as a whole, starting from searching for information until the consumption process is complete. Satisfied consumers will tend to be happy, while dissatisfied consumers will tend to be disappointed or sad. The emergence of happiness in consumers indicates satisfaction in consumers (Goldman, 2017). Consumers who feel happy about online purchases made can be said to feel the purchase's satisfaction.

Consumers' happiness toward product purchases in Zhu et al, (2015) is associated with joy toward gift with purchase received. In the study, it was said that happiness toward gift with purchase influences consumer satisfaction. It shows that gift with purchase is very important for online shop owners in carrying out their business. If consumers are satisfied with a shopping, it will increase online store sales and owner income, and vice versa. Happiness is a form of emotion associated with objects, facts, and circumstances (Goldman, 2017). The same source stated that "I am happy with the recent stock market movements" is a form of the statement that associates happiness with an object. When we talk about happy people, we will refer to people with pleasant emotions, who tend to feel happy or in a good mood (Goldman, 2017). The happy feeling is an emotion, such as feeling angry, scared, or jealous and proud. A person can feel happy in a bad situation when the person has worse expectations (Goldman, 2017). Conversely, if someone has terrible expectations but gets a worse reality, that person will feel unhappiness.

As in the emotional assessment theory, occasions considered harmful would cause negative emotions, while circumstances deemed beneficial will generate positive emotions (Zhu, Chang, \& Chang, 2015). Consuming gift with purchases can trigger happiness as a positive emotion (Zhu, Chang, \& Chang, 2015). It is also said that happiness is used to describe consumers' emotional state towards gift with purchase in the context of online purchases. Happiness is obtained from consumer evaluations of gifts with purchases received through usability, quality, authenticity, and cost.

This research also examines whether there is a positive relationship between the happiness of the consumers of gift with purchase to overall online purchase satisfaction. Happiness is a form of emotion (Goldman, 2017) as one way to express shopping experiences (Thuraru et al. 2006). Based on this theory, this research conducted a test to determine whether there is a positive relationship between the happiness of the consumers of gift with purchase to the overall happiness of the consumers. Based on these things, the hypothesis is arranged as followed:

H5: Happiness toward gift with purchase positively influences the purchase satisfaction of consumers.

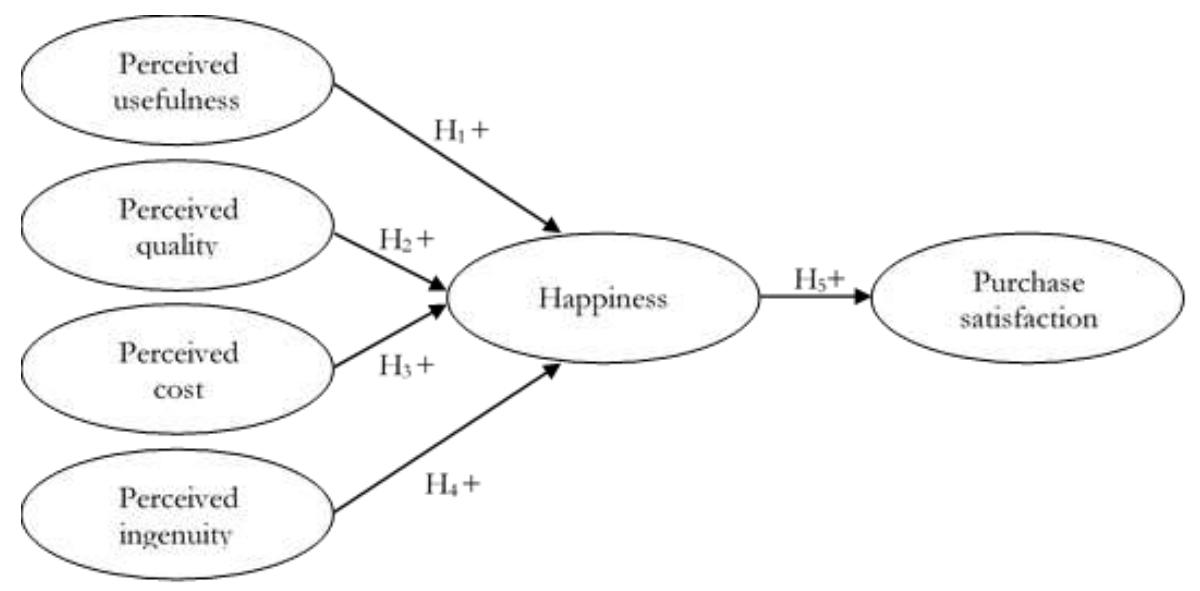

Figure 1. Proposed model 


\section{Methods}

An online survey was done to gather data from our targeted respondents who once purchased in one of the online stores on one of the predefined social media (Facebook, Instagram, and Youtube) for a minimum of one time in the past six months and received a gift with purchase from online stores for their online purchases. Six variables according to Zhu et al. (2015) were used and measured through several items: perceived usefulness (4 items), perceived quality (4 items), perceived costs ( 3 items), perceived ingenuity (4 items), happiness of consumers ( 3 items), and consumer purchase satisfaction (3 items). Each statement item used a 5 -point Likert scale ranging from 1 (strongly disagree), 2 (disagree), 3 (neutral), 4 (agree), and 5 (strongly agree).

The researchers collected 276 responses, yet only 207 responses $(76.1 \%)$ were valid. Preliminary analysis of classical assumption proved that all data showed no abnormalities and adequate for further data analysis. Validity and reliability test were undertaken and purify our instruments as two variables from the perceived ingenuity variable needed to be eliminated due to low factor loading value (Sekaran \& Bougie, 2013). Results of validity and reliability test for measurement evaluation are summarized in Table 1.

Table 1. Measurement Evaluation

\begin{tabular}{lccc}
\hline \multicolumn{1}{c}{ Variables } & Items & Factor Loading & Cronbach's Alpha \\
\hline Perceived Usefulness & PU1 & 0.796 & 0.890 \\
& PU2 & 0.825 & \\
& PU3 & 0.793 & \\
& PU4 & 0.752 & 0.906 \\
\hline Perceived Quality & PQ1 & 0.778 & \\
& PQ2 & 0.750 & \\
& PQ3 & 0.800 & 0.780 \\
& PQ4 & 0.822 & \\
\hline Perceived Cost & PC1 & 0.784 & 0.760 \\
& PC2 & 0.779 & 0.817 \\
\hline Perceived Ingenuity & PC3 & 0.807 & \\
& PIG3 & 0.868 & \\
\hline Happiness & PIG4 & 0.860 & 0.862 \\
& HP1 & 0.843 & \\
\hline Purchase Satisfaction & HP2 & 0.864 & \\
& HP3 & 0.651 & \\
& PST1 & 0.828 & \\
& PST2 & 0.731 & \\
\hline Sour & PST3 & 0.806 & \\
\hline
\end{tabular}

Source: Primary data processed, 2018

\section{Results and Discussion}

\section{Demographics of Respondents}

Our respondents consisted mainly of women $(73.4 \%)$ in the age range of 13 to 21 years old $(67.1 \%)$, graduated from senior high school $(76.8 \%)$, currently a student $(92.3 \%)$ and spent their monthly expenditure between IDR700,000 to IDR1,500,000 per month (75.3\%). The detailed characteristics of our respondents are shown in Table 2 . These characteristics matched with attributes of the Millennial generation that serves typical behavior in utilizing technology. Millennial generation tended to be heavy users of social media and strive for practicality in their lives. They had limited resources to spent and search for optimum choices for all their purchase transaction. Thus, results of this research were generalized specifically for a particular generation with specific behavior. 
Table 2. Demographic Characteristics of Respondents $(\mathbb{N}=207)$

\begin{tabular}{|c|c|c|c|}
\hline No & Characteristics & Frequency & Percentage \\
\hline \multirow[t]{3}{*}{1} & Gender & & \\
\hline & Male & 55 & 26.6 \\
\hline & Female & 152 & 73.4 \\
\hline \multirow[t]{4}{*}{2} & Age Range & & \\
\hline & $13-21$ & 139 & 67.1 \\
\hline & $22-29$ & 67 & 32.4 \\
\hline & $30-44$ & 1 & 0.5 \\
\hline \multirow[t]{6}{*}{3} & Educational Background & & \\
\hline & Junior High & 1 & 0.5 \\
\hline & Senior High & 159 & 76.8 \\
\hline & Diploma & 12 & 5.8 \\
\hline & Bachelor & 34 & 16.4 \\
\hline & Master & 1 & 0.5 \\
\hline \multirow[t]{7}{*}{4} & Occupation & & \\
\hline & Freelance & 2 & 1 \\
\hline & Private sector & 9 & 4.3 \\
\hline & Student & 191 & 92.3 \\
\hline & Researcher & 1 & 0.5 \\
\hline & Government sector & 1 & 0.5 \\
\hline & Entrepreneur & 3 & 1.4 \\
\hline \multirow[t]{7}{*}{5} & Monthly Expense & & \\
\hline & $<$ IDR700,000.00 & 57 & 27.5 \\
\hline & IDR700,001.00 - IDR1,000,000.00 & 48 & 23.2 \\
\hline & IDR1,000,001.00 - IDR1,500,000.00 & 51 & 24.6 \\
\hline & IDR1,500,001.00 - IDR2,000,000.00 & 27 & 13.0 \\
\hline & IDR2,000,001.00 - IDR3,000,000.00 & 15 & 7.2 \\
\hline & $>$ IDR $3,000,000.00$ & 9 & 4.3 \\
\hline
\end{tabular}

Source: Primary data processed, 2018

\section{Descriptive Statistics}

Table 3. Descriptive Statistics

\begin{tabular}{|c|c|c|c|c|c|}
\hline Variables & Mean & SD & Items & Mean & SD \\
\hline \multirow[t]{4}{*}{ Perceived usefulness } & 3.6461 & 0.79100 & PU1 & 3.952 & 0.8170 \\
\hline & & & PU2 & 3.459 & 0.9384 \\
\hline & & & PU3 & 3.300 & 1.0274 \\
\hline & & & PU4 & 3.874 & 0.8497 \\
\hline \multirow[t]{4}{*}{ Perceived quality } & 3.5181 & 0.81325 & PQ1 & 3.599 & 0.8969 \\
\hline & & & PQ2 & 3.188 & 1.0040 \\
\hline & & & PQ3 & 3.614 & 0.9113 \\
\hline & & & PQ4 & 3.671 & 0.8673 \\
\hline \multirow[t]{3}{*}{ Perceived cost } & 3.1965 & 0.87519 & PC1 & 3.198 & 1.0769 \\
\hline & & & PC2 & 3.449 & 1.0078 \\
\hline & & & PC3 & 2.942 & 1.0642 \\
\hline \multirow[t]{2}{*}{ Perceived ingenuity } & 3.1643 & 1.14996 & PIG3 & 3.077 & 1.3123 \\
\hline & & & PIG4 & 3.251 & 1.2482 \\
\hline \multirow[t]{3}{*}{ Happiness } & 4.1852 & 0.60344 & HP1 & 4.324 & 0.5966 \\
\hline & & & $\mathrm{HP} 2$ & 4.193 & 0.7316 \\
\hline & & & $\mathrm{HP} 3$ & 4.039 & 0.7749 \\
\hline \multirow[t]{3}{*}{ Purchase satisfaction } & 3.9630 & 0.66198 & PST1 & 3.966 & 0.7333 \\
\hline & & & PST2 & 3.918 & 0.7491 \\
\hline & & & PST3 & 4.005 & 0.7600 \\
\hline
\end{tabular}

Source: Primary data processed, 2018 
Table 3 summarizes descriptive statistics for all variables examined. As shown in Table 3, Happiness had the highest mean value (4.1852), which means that our respondents indicated positive emotions upon receiving a gift with purchase. Perceived Ingenuity served as the variable with the lowest mean value (3.1643). It implies that consumers felt the gift from their purchase was not that extraordinary and assumed not as original as from the online store.

\section{Model Summary}

This research used two equations to test our proposed model. The detail of the result is summarized in Table 4. It can be concluded from Equation 1 that perceived usefulness $(\beta=0.252$, $p$-value $=$ $0.000)$ and perceived quality $(\beta=0.245$, $p$-value $=0.002)$ influenced happiness when consumers received free gift. Further, happiness $(\beta=0.530, p$-value $=0.000)$ in receiving free gift significantly influenced purchase satisfaction. From the five hypotheses, only three were proven to influence other variables examined.

Table 4. Model summary

\begin{tabular}{lllll}
\hline & Variable relationship & & \multirow{2}{*}{ Equation 1 } & \multirow{2}{*}{ Equation 2 } \\
\cline { 2 - 4 } & Independent Variable & Dependent Variable & & \\
\hline $\mathrm{H}_{1}$ & Perceived usefulness & Happiness & $0.252\left(3.307^{* * *}\right)$ & \\
$\mathrm{H}_{2}$ & Perceived quality & Happiness & $0.245\left(3.093^{* *}\right)$ & \\
$\mathrm{H}_{3}$ & Perceived cost & Happiness & $0.073(1.074)$ & \\
$\mathrm{H}_{4}$ & Perceived ingenuity & Happiness & $0.071(1.115)$ & \\
$\mathrm{H}_{5}$ & Happiness & Purchase Satisfaction & & $0.530\left(8.957^{* * *}\right)$ \\
& & Adjusted $-\mathrm{R}^{2}$ & 0.239 & 0.278 \\
& & $F$ & $17.133^{* * *}$ & $80.226^{* * *}$ \\
\hline
\end{tabular}

***sig $<0.001 ; * *$ sig $<0.005$

Source: Primary data processed, 2018

The increased use of social media in business transactions had opened enormous opportunities for new business, especially the small-scale home-based business. This research tried to see whether gift with purchase was useful in social media marketing as one strategy to keep consumers satisfied in the intense and competitive market configuration.

Perceived usefulness of gift with purchase was proven to have a positive influence on happiness. Gift with purchase provided by online sellers was considered beneficial and useful for consumers; thus, becoming a strong reason to buy or own products since the gift was seen as providing more value and benefit. Online store owners must consider consumers' evaluation of product usability in social media upon choosing products to be used as a gift to be delivered to consumers. Gift with purchase that is beneficial to the daily lives of consumers would provide happiness to consumers.

Perceived quality of gift with purchase was also proven to have a positive influence on happiness. The higher quality of gifts will lead to greater consumer happiness. It made sense because good quality products tend to be more durable. Consumers certainly do not want to pay more when the consumption process is finished, especially gift with purchase is obtained free of charge.

This research and previous research proved that perceived quality had a positive relationship with the happiness of consumers. The higher the quality of a product received, the greater the happiness consumers feel for online purchases. Gift with purchases with high quality can increase sales of the products being promoted (Zhu, Chang, \& Chang, 2015). Based on the research result, quality is the leading indicator for consumers to assess gifts with purchase. Online seller on social media must consider quality in carrying out a promotional gift with purchase strategies so that the strategy will be effective and efficient to increase product sales.

This research proved that the perceived cost of a gift with purchase did not positively influence happiness. Through these researches, it is known that consumers tended to override perceived cost attributes in evaluating received gifts with purchases. Consumers did not need to make 
more sacrifices to get a gift with purchases. Consumers knew for sure that gift with purchase fees were fully charged to online shop seller. Therefore, perceived cost was not included as a factor that influences consumers' happiness in online shopping on social media.

Previous research explained that the perceived cost had a certain degree of influence on happiness, contrary to the findings. Marketers and online sellers tended to show attractive gifts with relatively high value to stimulate sales. The perceived cost had a significant positive correlation with consumers' happiness when consumers did not know that they will get a gift with purchase. However, when consumers knew regarding gift with purchase, the relationship between perceived cost and happiness becomes insignificant. The phenomenon was probably caused by differences in expectations and types of gifts with purchase products used when this research was conducted.

This research proved that the perceived ingenuity of gift with purchase did not positively influence consumer happiness. Consumers did not consider the attributes of gift with purchase. In previous research, perceived ingenuity positively influenced it if it was within the scope of uncertainty. This research did not assume consumer certainty and uncertainty regarding the existence of a gift with purchase before transactions. This hypothesis was not supported because consumers already knew regarding gifts with purchases before purchasing products on the promotional announcements made by marketers and online sellers. This made consumers felt that the gift received was not attractive or did not give a surprising impression as in previous research.

This research proved that consumer happiness towards gift with purchase had a positive influence on consumer satisfaction. If consumers feel the joy of gifts with purchases, they will feel purchasing social media. Satisfaction arose because consumers thought that the gift with purchase provided many value-added for online purchases made on social media.

The research result indicated that $\mathrm{H} 5$ was supported, which means consumers' happiness toward a gift positively influences consumer purchase satisfaction. Happiness had a value of $\beta$ of 0.530 , with a significance level of 0.000 . When seeing from the high value of $\beta$ of happiness, happiness had a strong influence on consumer purchase satisfaction. The result of this research indicated that happiness was involved in the process of evaluating consumer purchases for the gift. The higher the happiness that consumers felt can probably have result in higher purchase satisfaction. This result was linear with the previous research by Zhu, Chang, and Chang (2015). The fifth hypothesis proved that consumers felt satisfied in making purchases at online stores on social media.

\section{Conclusion}

This research found that perceived usefulness and perceived quality significantly influenced happiness on a gift with purchase, and that happiness served as a significant predictor for online purchase satisfaction through social media platform for millennials. The results of this research may benefits managers in revising their online promotion strategies. First and foremost, marketers and online shop sellers should maintain the happiness of consumers. This research found that consumers felt happy, pleased, and satisfied after receiving gift with purchase. Satisfied consumers had a high probability of making other purchases. Therefore, it is crucial for marketers and online shop sellers to always implement gifts with purchase strategies simply because consumers like it. One way for marketers and online shop sellers to maintain the level of happiness and satisfaction of consumer purchases was to maintain good relationships with consumers. Consumers who felt happy with the online store will feel the purchase's satisfaction.

Marketers and online shop sellers on social media should pay attention to the product's usefulness that will be used as a gift with purchase. Of the four factors used to assess the perceived benefit of gift with purchase, consumers tended to be neutral in the importance of whether gift with purchase can meet consumer needs. This condition was crucial for marketers and online shop sellers to always enjoy gift with purchase through its usefulness. For example, complementary products had strong use-value associations for the main products so that consumers could get definite benefits from gifts with purchase. The company could also provide a choice of gift with purchase products that consumers want. It is hoped that consumers could get gift with purchases as desired so that gift with purchases could be useful and vital for consumers. 
Marketers and online shop sellers on social media should pay attention to the level of quality of products used as gifts with purchases. This step was necessary to ensure that consumers would still get the highest quality products even though the product was provided free of charge. The quality of gifts with purchase provided needed to be safeguarded by marketers and online shop sellers so that consumers would not feel disappointed with the purchases made. Marketers could deliver gifts with purchases with a high level of reliability. To guarantee this, marketers and online shop sellers needed to ensure that gifts with purchases given to consumers were produced from high-quality materials and through production processes that comply with applicable standards. Besides, before the gift with purchase was delivered to consumers, it must first go through a quality feasibility test to ensure that purchases were fair and decent.

Marketers and online shop sellers on social media should pay attention to consumers' costs from gift with purchase. However, the perceived cost did not have a positive influence on happiness. Consumers tended to be neutral toward the item's statements which were given around perceived costs of gift with purchase because individual perceived cost differently. The greater cost incurred would not guarantee that the strategy could run effectively and efficiently. Also, not all consumers were satisfied with the gift with expensive purchases and vice versa. Marketers and online shop sellers needed to pay attention to the costs incurred to provide a gift with purchases that were per consumers' needs to the fullest. This effort was also carried out to maintain the business operations of online stores that were run financially.

Marketers and online shop sellers should pay attention to the ingenuity of gifts with purchases given to consumers. Although this variable did not positively influence the research model, marketers and online shop sellers on social media still need to pay attention to aspects of ingenuity by giving a unique and unusual gift with purchases. Gift with purchases that were not unique would not attract consumers' attention. For this reason, a gift with purchase was needed to attract consumers' attention so that it is expected to make transactions. Further research is required to find out the types of gifts with purchases of interest and unique to consumers.

This research had limitations. Firstly, this research did not include the respondents' domicile, so more detailed information on respondents' distribution was unknown. Secondly, this research did not categorize respondents based on types of social media and product categories. Therefore, future study might consider more demographic information. Further study may investigate the influence of gift with purchase-on-purchase satisfaction based on product type (utilitarian and hedonic types), suitability between gift with purchase and main products, and the influence of uncertainty and uncertainty conditions on the gift with purchase.

\section{References}

APJII. (2017). Penetrasi dan perilaku pengguna internet Indonesia. Jakarta: Asosiasi Penyelenggara Jasa Internet Indonesia.

Beltramini, R. (2000). Exploring the effectiveness of business gifts: replication and extension, Journal of Advertising, 29(2), 75-78.

Brady, M.K., \& J.J. Cronin. (2001). Some new thoughts on conceptualizing perceived service quality: a hierarchial approach. Journal of Marketing. 65 (3): 34-50.

Chen, L. D. (2012). Developing the index for product design communication and evaluation from emotional perspectives. Expert System with Application, 39(2), 2011-2020.

Chiu, C. M., Chang, C. C., Cheng, H. L., \& Fang, Y. H. (2009). Determinants of online customer repurchase intention in online shopping. Online Information Review, 33(4), 761-784.

Chun, H. H., \& Hiang, Y. W. (2016). Free drink or free mug? Managing service experience with experiential vs material complimentary gifts. Service Science, 8(2), 184-202.

Databoks. (2016, October 7). Retrieved from Google: Terbesar di ASEAN, pasar e-commerce Indonesia US $\$ 1,7$ miliar pada 2015: http://databoks.katadata.co.id/datapublish/2016/10/07/google-terbesar-di-asean-pasar-e-commerce-indonesia-us-17-miliar- 
pada-2015.

Davis, F. D., Bagozzi, R. P., \& Warshaw, P. R. (1989). User acceptance of computer technology: a comparison of two theoretical models. Management Science, 35(8), 982-1003.

Derbaix, C., \& Vanhamme, J. (2003). Inducing word-of-mouth by eliciting surprise a pilot investigation. Journal of Economic Psychology, 24(1), 99-116.

Dodds, W. B. (1991). Effects of price, brand, and store information on buyers product evaluations. Journal of Marketing Research, 28(3), 307-319.

Gaw, M. (2016, December 28). The Jakarta Post. Retrieved from Fintech talk: maintaining market share of social commerce: http://www.thejakartapost.com/news/2016/12/28/fintechtalk-maintaining-market-share-of-social-commerce.html.

Gatignon, H., \& Xuereb, J. (1997). Strategic Orientation of the Firm and New Product Performance. Journal of Marketing Research, 34(1), 77-90.

Goldman, A. H. (2017). Happiness is an emotion. Journal of Ethics, 21(1), 1-16.

Kemp, S. (2017). Southeast Asia: a study of internet, social media and mobile use throughout the region. Southeast Asia. Retrieved from We Are Social PDF eBook.

Khan, I., Rahman, Z., \& Fatma, M. (2016). The concept of online corporate brand experience: an empirical assessment. Marketing Intelligence and Planning, 34(5), 711-730.

Kim, H. J., \& Koo, J. (2015). Stand-alone sale as a free gift: is it effective to accentuate promotion value? Social Behavior and Personality, 43(10), 1593-1606.

Krutaine, A. (2016, November 10). Tech in Asia. Retrieved from will social commerce stunt the growth of e-commerce in Southeast Asia? https://www.techinasia.com/talk/social-commerce-stunt-growth-ecommerce-southeast-asia

Lee, S., \& Yi, Y. (2017). Seize the deal, or return it losing your free gift: the effect of a gift-withpurchase promotion on product return intention. Journal of Psychology and Marketing, 34(3), 249-263.

Lee, S., \& Yi, Y. (2019). Retail is detail! Give consumers a gift rather than a bundle: promotion framing and consumer product returns. Psychology \& Marketing, 36(1), 15-27.

Moldovan, S., Goldenberg, J., \& Chattopadhyay, A. (2011). The different roles of product originality and usefulness in generating word of mouth. International Journal of Research in Marketing, 28(2), 109-119.

Rojas, C. D., \& Camarero, C. (2008). Visitors experience, mood and satisfaction in a heritage context: evidence from an interpretation center. Tourism Management, 29(3), 525-537.

Sekaran, U., \& Bougie, R. (2013). Research methods for business. Chichester: John and Wiley and Sons Ltd.

Simamora, Bilson. (2002). Panduan Riset Perilaku Konsumen. PT Gramedia Pustaka Utama, Jakarta

Thuraru, T., Groth, M., Paul, M., \& Gremler, D. D. (2006). Are all smiles created equal? How emotional contagion and emotional labor affect service relationships. Journal of Marketing, 70(3), 58-73.

Vanhamme, J. D. (2008). Surprise gift purchase: customer insight from the small electrical appliances market. Journal of retailing, 84(3), 354-369.

Zhu, D. H., Chang, Y. P., \& Chang, A. (2015). Effects of free gifts with purchase on online purchase satisfaction: the moderating role of uncertainty. Internet Research, 25(5), 690-706. 
Appendix

Perceived usefulness

PU1 The free gift with purchase I received is useful

PU2 The free gift with purchase I received fulfils my needs

PU3 The free gift with purchase I received is important

PU4 The free gift with purchase I received is beneficial

Perceived quality

PQ1 The quality of free gift with purchase is reliable

PQ2 The free gift is made by expert

PQ3 The quality of free gift is guaranteed

PQ4 The free gift with purchase has good quality

Perceived cost*

PC1 Evaluating from the cost to make the free gift, I think the owner is frugal

PC2 The quality of free gift is low

PC3 The cost to get free gift with purchase is low

Perceived ingenuity

PIG3 The free gift with purchase is unusual

PIG4 The free gift with purchase is unique

Happiness

HP1 I feel happy when I see the free gift purchase

HP2 The free gift with purchase make me happy

HP3 The free gift with purchase make me satisfied

Purchase satisfaction

PST1 I am happy with my decision to buy from this store

PST2 I am doing the right thing in choosing this store that give free gift with purchase

PST3 Overall, I am satisfied with my decision to buy from an online store that give free gift with purchase 